\title{
STUDI KOMPARATIF PENDAPATAN USAHATANI LABU KUNING ANTARA PETANI YANG BERMITRA DAN NON MITRA DI KABUPATEN SITUBONDO
}

\author{
Kinsai $^{1)}$, Yohanes Nangameka ${ }^{2 *}$ \\ Program Studi Agribisnis, Fakultas Pertanian, Universitas Abdurachman Saleh Situbondo \\ Email Korespondensi : comodo.consultan@yahoo.co.id
}

\begin{abstract}
Abstrak
Tujuan dari penelitian ini adalah ingin menganalisis perbedaan produksi dan perbedaan pendapatan serta efisiensi usahatani labu kuning antara petani yang bermitra dan non mitra di Kabupaten Situbondo. Penentuan daerah penelitian ditentukan secara purposive sampling yang dipilih berdasarkan tujuan tertentu yang dipandang sesuai dengan tujuan penelitian. Metode Slovin dalam penelitian digunakan untuk menentukan jumlah sampel. Jumlah sampel yang digunakan dalam penelitian ini adalah sebanyak 43 sampel terdiri dari 18 usahatani labu kuning sistem kemitraan dan 25 usahatani sistem non kemitraan. Hasil dari penelitian ini adalah : total produksi usahatani labu kuning sistem kemitraan adalah sebanyak $270.720 \mathrm{~kg}$ per periode tanam sedangkan sistem non kemitraan adalah sebanyak $11.600 \mathrm{~kg}$ per periode tanam dan total pendapatan usahatani labu kuning sistem kemitraan sebesar Rp. 514.053.839 dan non kemitraan sebesar Rp. 27.187.000 dan efisiensi sistem kemitraan sebesar 3,42 dan non kemitraan sebesar 3,94. Hasil uji beda tingkat produksi diperoleh $\mathrm{t}$ hitung $>\mathrm{t}$ tabel dan tingkat pendapatan diperoleh $\mathrm{t}$ hitung $>\mathrm{t}$ tabel serta tingkat efisiensi diperoleh $\mathrm{t}$ hitung $<\mathrm{t}$ tabel. Hasil penelitian menunjukan bahwa terdapat perbedaan produksi dan perbedaan pendapatan serta perbedaan efisiensi usahatani labu kuning antara sistem kemitraan dan non kemitraan.
\end{abstract}

Kata kunci : Labu kuning, Usahatani, Kemitraan

\begin{abstract}
The purpose of this study was to determine the comparison of production levels, income and efficiency of pumpkin farming between farmers are partners and non partners. In analyzing the comparative hypotheses of production, income and efficiency using the $t$ test formula. The research area was determined by purposive sampling the research area was selected based on certain objectives which were considered in accordance with the research objectives. Determination of the sample in this study using Slovin's opinion that is sampling by determining the amount depending on the size of the sub-population or group to be represented. The number of samples used in this study were 43 samples consisting of 18 pumpkin partnership systems and 25 partnership systems farming. From the research, the results are obtained: Total production of pumpkin farming in partnership system is 270,720 $\mathrm{kg}$, non-partnership system is $11,600 \mathrm{~kg}$ per planting period. The results of different levels of production test obtained T count of $4.49 \mathrm{~T}$ table of 2.704. While the total income of the pumpkin partnership in the partnership system is Rp. 514,053,839 and non-partnership of Rp. 27,187,000 Different income test results obtained T count of $505.67 \mathrm{~T}$ table of 2.704. While the average level of efficiency of the partnership system is 3.42 and non-partnership is 3.94. Different test results for the level of efficiency obtained T count of $2.08 \mathrm{~T}$ table of 2.704 .

Keywords: Pumpkin, Farmers, Partnerships
\end{abstract}




\section{PENDAHULUAN}

Pertanian dalam arti luas adalah semua yang mencakup kegiatan pertanian (tanaman pangan dan hortikultura), perkebunan, kehutanan, perikanan dan peternakan. Sektor pertanian di Indonesia memegang peranan penting dari keseluruhan jenis perekonomian nasional. Salah satu sub sektor pertanian yang tidak kalah pentingnya dalam memenuhi kebutuhan dan meningkatkan pendapatan masyarakat yaitu sektor tanaman pangan dan hortikultura. Salah satu strategi yang dapat meningkatkan daya saing dalam bisnis tanaman pangan dan hortikultura adalah melalui kemitraan. Kemitraan usahatani adalah jalinan kerjasama usaha yang saling menguntungkan antara pengusaha kecil dengan pengusaha menengah atau besar (perusahaan mitra) disertai dengan pembinaan dan pengembangan oleh pengusaha besar dengan memperhatikan prinsip saling menguntungkan (Sutawi, 2004).

PT. East West Seed Indonesia adalah perusahaan pembenihan terpadu yang menghasilkan benih unggul yaitu benih sayuran melalui pemuliaan tanaman dengan kegiatan kemitraan bersama petani. Untuk memenuhi permintaan benih yang semakin meningkat, PT. East West Seed Indonesia menjalin kemitraan dengan banyak petani yang tersebar di berbagai tempat dalam sistem usaha pertanian kontrak (contract farming).

Kabupaten Situbondo merupakan salah satu Kabupaten di Jawa Timur yang memiliki sumberdaya lahan dan perairan yang sangat potensial untuk pengembangan pertanian dengan pendekatan agribisnis. Sektor pertanian yang berkembang di Situbondo sangatlah beragam, selain sebagai sentra produksi tanaman pangan seperti padi dan jagung, juga berpotensi dalam produksi tanaman hortikultura seperti sayuran dan buahbuahan, salah satunya adalah buah Labu kuning yang menjadi produk unggulan di Kecamatan Kendit terutama di Desa Kukusan.

Tujuan yang ingin dicapai dalam penelitian ini adalah:

1) Ingin menganalisis perbedaan produksi usahatani labu kuning antara petani yang bermitra dan non mitra di Kabupaten Situbondo dan ingin menganalisis perbedaan pendapatan usahatani labu kuning antara petani yang bermitra dan non mitra di Kabupaten Situbondo serta ingin enganalisis perbedaan efisiensi usahatani labu kuning antara petani yang bermitra dan non mitra di Kabupaten Situbondo.

\section{METODE PENELITIAN}

Penelitian dilakukan secara sengaja (purposive), penentuan daerah dalam penelitian ini dilakukan di Kabupaten Situbondo yaitu di Kecamatan Kendit, Kecamatan Panji dan Kecamatan Situbondo. Metode penelitian yang digunakan dalam penelitian ini adalah metode deskriptif dan kuantitatif. Jumlah populasi petani labu kuning adalah sebanyak 58 petani, terdiri dari 23 petani yang bermitra di Kecamatan Situbondo dan kecamatan Panji Kabupaten Situbondo kemudian 35 petani yang tidak bermitra di Kecamatan Kendit Kabupaten Situbondo. Teknik pengambilan sampel yang digunakan dalam penelitian adalah jenis sampling probabilitas, merupakan teknik yang memberikan peluang atau kesempatan yang sama bagi setiap unsur (anggota) populasi untuk dipilih menjadi anggota sampel dalam artian dimana jumlah populasi dalam penelitian ini sudah diketahui. Selanjutnya menentukan besarnya sampel yaitu dengan menggunakan pendapat Slovin, yaitu dengan menggunakan formulasi: 
Keterangan:

$$
\mathrm{n}=\frac{N}{1+N(e)^{2}}
$$

$\mathrm{n} \quad=$ Ukuran Sampel

$\mathrm{N} \quad=$ Ukuran Populasi

e $\quad=$ Persen kelonggaran ketidaktelitian karena pengambilan sampel yang masih dapat ditolerir (10\%).

Tabel 1. Data Sampel Penelitian Petani labu kuning berdasarkan status kemitraan

\begin{tabular}{lll}
\hline Status Kemitraan & Populasi & Sampel \\
\hline Petani Mitra & 23 Petani & 18 Petani \\
Petani Non Mitra & 35 Petani & 25 Petani \\
\hline Total & 58 Petani & 43 Petani \\
\hline
\end{tabular}

\section{Teknik Pengumpulan dan Jenis Data}

1. Kuisioner

Metode kuisioner merupakan teknik pengumpulan data yang dilakukan dengan cara memberi seperangkat pertanyaan atau pernyataan tertulis kepada responden untuk dijawab. Data yang diperoleh peneliti yakni dengan cara memberi angket.

2.Wawancara

Metode wawancara adalah proses memperoleh keterangan untuk tujuan penelitian dengan cara tanya jawab sambil bertatap mata antarara pewawancara dengan responden. Penelitian menggunakan wawancara terbuka.

3.Dokumentasi

Merupakan metode pengumpulan data dengan cara mencari data mengenai hal-hal atau variabel yang berupa catatan, transkip, buku, notulen, agenda dan sebagainya. Dokumen yang digunakan dalam penelitian ini berupa foto, gambar dll.

\section{Metode Analisis Data}

\section{Analisis Pendapatan}

$\mathrm{TR}=\mathrm{Y} \mathrm{x}$ Py

Keterangan :

TR : Total penerimaan (Rp)

Y : Jumlah produksi (Kg)

Py : Harga (Kg)

$\mathrm{Pd}=\mathrm{TR}-\mathrm{TC}$

Keterangan :

$\mathrm{Pd}$ : pendapatan petani

TR : Total revenue (total penerimaan)

TC : Total cost (total biaya)

\section{Analisis Efisiensi}

Rumus mencari tingkat efisiensi adalah:

$\mathrm{R} / \mathrm{C}$ ratio $=\mathrm{TR} / \mathrm{TC}$

Keterangan :

$\mathrm{R} / \mathrm{C}$ ratio : tingkat efisiensi

TR : Total revenue (total penerimaan)

TC : Total cost (total biaya) 


\section{Analisis Statistik}

Analisis Statistik Untuk menguji hipotesis pertama, kedua dan ketiga ; apakah terdapat perbedaan produksi, perbedaan pendapatan dan perbedaan efisiensi labu kuning antara petani yang bermitra dan non mitra, jika sampel < 30 orang maka digunakan uji t (Sugiyono, 2013) dengan rumus sebagai berikut:

$$
\text { thitung }=\frac{\bar{x}_{1-} \bar{x}_{2}}{\sqrt{\left(\frac{\left(\mathrm{n}_{1-1} 1\right) \mathrm{S}_{1}{ }^{2}+\left(\mathrm{n}_{2-} 1\right) \mathrm{S}_{2}{ }^{2}}{\mathrm{n}_{1}+\mathrm{n}_{2}-2}\right)\left(\frac{1}{\mathrm{n}_{1}}+\frac{1}{\mathrm{n}_{2}}\right)}}
$$

Keterangan:

$\mathrm{X}_{1}=\mathrm{Rata}-$ rata produksi, pendapatan, efisiensi labu kuning mitra

$\mathrm{X}_{2}=$ Rata - rata produksi, pendapatan, efisiensi labu kuning non mitra

$\mathrm{S}_{1}=$ Varian produksi , pendapatan, efisiensi labu kuning mitra

$\mathrm{S}_{2}=$ Varian produksi , pendapatan, efisiensi labu kuning non mitra

$\mathrm{n}_{1}=$ Jumlah sampel petani labu kuning mitra

$\mathrm{n}_{2}=$ Jumlah sampel petani labu kuning nonmitra

Kriteria pengambilan keputusan :

$\mathrm{H} 0=\pi 1-\pi 2=0$, tidak terdapat perbedaan produksi, pendapatan, efisiensi antara petani mitra dan nonmitra.

$\mathrm{H} 1=\pi 1-\pi 2 \neq 0$, terdapat perbedaan produksi, pendapatan, efisiensi antara petani mitra dan nonmitra.

\section{HASIL DAN PEMBAHASAN}

Tabel 2. hasil uji t perbedaan produksi usahatani labu kuning sistem kemitra dan non mitra.

\begin{tabular}{ccccc}
\hline Variabel & $\begin{array}{c}\text { Sistem } \\
\text { usahatani }\end{array}$ & $\begin{array}{c}\text { Produksi } \\
\text { rata-rata }(\mathrm{kg})\end{array}$ & T hitung & T tabel \\
\hline $\mathrm{X}_{1}$ & Kemitraan & $\begin{array}{c}15.375,55 \\
464\end{array}$ & 4,49 & 2,704 \\
$\mathrm{X}_{2}$ & Non Mitra & \begin{tabular}{c}
464 \\
\hline
\end{tabular}
\end{tabular}

Tabel diatas merupakan hasil uji $\mathrm{t}$ untuk mengetahui perbedaan produksi usahatani labu kuning sistem kemitraan dan non kemitraan. Produksi rata-rata sistem kemitraan adalah sebanyak $15.375,55 \mathrm{~kg}$, untuk tiap responden/periode tanam dan non kemitraan sebanyak $464 \mathrm{~kg}$, untuk tiap responden/periode tanam. Hasil uji t menunjukan $\mathrm{T}$ hitung senilai 4,49 sedangkan $\mathrm{T}$ tabel senilai 2,704 . Nilai $\mathrm{T}$ hitung lebih besar dari pada $\mathrm{T}$ tabel artinya terdapat perbedaan produksi yang signifikan antara usahatani labu kuning sistem kemitraan dan non mitra pada tingkat kepercayaan 0,01 atau 99\%. Pada usahatani labu kuning sistem kemitraan produksi lebih tinggi daripada sistem non kemitraan, produksi tertinggi mencapai $22.400 \mathrm{~kg} / \mathrm{ha}$ sedangkan produksi terendah sebanyak $11.200 \mathrm{~kg} / \mathrm{ha}$. Produksi yang tinggi ini karena jumlah populasi labu kuning yang diberikan oleh perusahaan PT.EWSI kepada petani untuk dibudidayakan juga banyak. Jumlah populasi untuk tiap luas lahan berbeda-beda dan tergantung kemampuan petani dalam membudidaya labu kuning, untuk lahan seluas 0,1 ha jumlah populasi yang diberikan kepada petani sebanyak 1400 populasi dan luas lahan 0,2 ha jumlah populasi sebanyak 1430 - 2400 populasi sedangkan luas lahan 0,3 ha jumlah populasi sebanyak 2400 - 2800 populasi. Dengan banyaknya jumlah populasi labu kuning yang diberikan kepada petani sehingga jumlah produksi pun banyak, tetapi tidak lepas dari sistem pemiliharaan yang baik mulai dari penanaman,pemberian pupuk hingga perawatan dari gulma, hama dan penyakit sehingga tanaman sehat dan menghasilkan produksi yang tinggi. Sedangkan pada usahatani labu kuning non kemitran jumlah produksi lebih rendah daripada kemitraan. Rendahnya produksi usahatani sistem kemitraan karena proses budidaya menerapkan 
sistem tumpangsari, dimana sistem tanam adalah setelah tanam jagung lalu disusul dengan menanam labu kuning serta tanaman lainnya, jumlah populasi labu kuning yang ditanam memang banyak tetapi sistem budidaya dan pemiliharaannya tidak seperti sistem kemitraan. Pada sistem non kemitraan budidaya dan pemeliharaannya tidak mengunakan pupuk, serta obat/pestisida sehingga produksinya tidak bisa meningkat, dan penanamannya dilahan ladang/tegal, beda halnya dengan sistem kemitraan.

Tabel 3. Hasil uji t perbedaan tingkat pendapatan usahatani labu kuning sistem kemitraan dan non kemitraan.

\begin{tabular}{ccccc}
\hline Variabel & $\begin{array}{c}\text { Sistem } \\
\text { usahatani }\end{array}$ & $\begin{array}{c}\text { Pendapatan } \\
\text { rata-rata (Rp) }\end{array}$ & T hitung & T tabel \\
\hline $\mathrm{X}_{1}$ & Kemitraan & $\begin{array}{c}28.558 .546 \\
1.087 .480\end{array}$ & \multirow{2}{*}{505,67} & 2,704 \\
$\mathrm{X}_{2}$ & Non Mitra & 1.0804 & \multirow{2}{*}{}
\end{tabular}

Dari tabel diatas dapat dilihat bahwa pendapatan rata-rata keseluruhan responden usahatani labu kuning sistem kemitraan adalah sebesar Rp. 28.558 .546 sedangkan sistem non kemitraan pendapatan rata-rata keseluruhan responden sebesar Rp. 1.087.480. Hasil perhitungan menggunakan alat statistik dengan hasil $\mathrm{T}$ hitung 505,67 sedangkan $\mathrm{T}$ tabel 2,704 . Dapat disimpulkan bahwa terdapat perbedaan pendapatan yang signifikan antara usahatani labu kuning sistem kemitraan dan non kemitraan pada tingkat kepercayaan 99\%. Pendapatan usahatani labu kuning sistem kemitraan jauh lebih besar daripada sistem non kemitraan karena produksinya jauh lebih tinggi dibandingkan dengan produksi sistem non kemitraan. Pendapatan tertinggi usahatani sistem kemitraan yang di terima petani mencapai Rp. 51.682.000 dan terendah sebesar Rp. 15.995.000 untuk masing-masing luas lahan. Sedangkan pada sistem non kemitraan pendapatan tertinggi yang diterima petani mencapai Rp.1.055.000 dan terendah mencapai Rp.740.000. Pendapatan sistem non kemitraan lebih rendah daripada sistem kemitraan karena jumlah produksinya juga sangat rendah walaupun harga beli dipasar adalah sama yaitu sebesar Rp. $3000 / \mathrm{kg}$.

Tabel 4. Hasil uji t perbedaan tingkat efisiensi usahatani labu kuning sistem kemitraan dan non kemitraan.

\begin{tabular}{ccccc}
\hline Variabel & $\begin{array}{c}\text { Sistem } \\
\text { Usahatani }\end{array}$ & $\begin{array}{c}\text { Efisiensi } \\
\text { rata-rata (Rp) }\end{array}$ & T hitung & T tabel \\
\hline $\mathrm{X}_{1}$ & Kemitraan & 3,42 & 2,08 & 2,704 \\
$\mathrm{X}_{2}$ & Non Mitra & 3,94 & 2,08 & \\
\hline
\end{tabular}

Dari tabel diatas dapat dilihat bahwa efisiensi rata-rata keseluruhan usahatani labu kuning sistem kemitraan adalah senilai 3,42 sedangkan sistem non kemitraan efisiensi rata-rata senilai 3,94. Hasil perhitungan menggunakan alat statistik dengan hasil $\mathrm{T}$ hitung 2,08 sedangkan $\mathrm{T}$ tabel 2,704. Dapat disimpulkan bahwa tidak terdapat perbedaan efisiensi yang signifikan antara usahatani labu kuning sistem kemitraan dan non kemitraan pada tingkat kepercayaan 99\%. Nilai efisiensi usahatani labu kuning sistem non kemitraan lebih besar daripada nilai efisiensi labu kuning sistem kemitraan karena pada usahatani sistem non kemitraan biaya yang dikeluarkan/diperlukan lebih sedikit dibandingkan dengan usahatani sistem kemitraan. Pada usahatani labu kuning sistem non kemitraan, proses budidaya tidak menggunakan pupuk, pestisida, tidak menyewa lahan, tidak membayar upah dan biaya lainnya, dalam proses budidaya, menerapkan sistem tumpang sari dimana penanaman labu kuning dimulai setelah panen jagung. Sehingga biaya yang dikeluarkan untuk proses budidaya sangat sedikit hanya membeli peralatan,perlengkapan seperti arit untuk penyiangan tanaman dan transportasi. Lain halnya dengan usahatani labu kuning sistem kemitraan hampir semua proses budidaya 
membutuhkan biaya yang banyak mulai dari sewa lahan sampai panen, sehingga biaya yang dikeluarkan sangat banyak. Nilai efisiensi usahatani labu kuning sistem kemitraan tertinggi senilai 4,73 terendah senilai 1,87 sedangkan sistem non kemitraan nilai efisiensi tertinggi senilai 4,8 dan terendah senilai 3,1 untuk masing- masing responden. Kedua sistem usahatani labu kuning ini pada dasarnya memiliki nilai rata-rata efisiensi yang tidak jauh berbeda, artinya usahatani baik sistem kemitraan maupun non kemitraan masih menguntungkan bagi petani.

\section{KESIMPULAN}

1. Terdapat perbedaan produksi usahatani labu kuning antara sistem kemitraan dan non kemitraan.

2. Terdapat perbedaan pendapatan usahatani labu kuning antara sistem kemitraan dan non kemitraan.

3. Terdapat perbedaan efisiensi usahatani labu kuning antara sistem kemitraan dan non kemitraan.

\section{REFERENSI}

Anonymous. 1996. Pengembangan Model Kemitraan Agribisnis, PT. Pusat Pengembangan Agribisnis, Departemen Pertanian.

Gutama, I.B, K. 2000. Pola Kemitraan Antara Petani Jahe Gajah Dengan Perusahaan Jahe Asinan di Kabupaten Bangli. Jurnal penelitian. Jurusan Sosek Pertanian UNUD: Denpasar.

Hidayah, 2010. Manfaat dan Kandungan Gizi Labu Kuning (waluh). http://www.borneotribune.com (diakses 26 Mei 2019).

Hedrasty, 2011. Kandungan Labu Kuning dan Pemanfaatannya. Kanisius, Yogyakarta.

Harahap, Hasrul 1985. Perkebunan dan peranannya dalam perekonomian Indonesia. Agroekonomika.

Hasyim, 2012. Tataniaga Pertanian. Diktat Kuliah, Fakultas Pertanian Universitas Lampung.

Hafsah. J. M. 1999, Kemitraan Usaha Konsepsi dan Strategi, Pustaka Sinar Harapan Jakarta.

Hamidah E, Tri Wahyurini E, Zunaidi, H. 2018. Analisis Efisiensi Usahatani Sistem Kemitraan Produksi Benih Pare. Jurnal Penelitian. Universitas Islam Darul Ulum Lamongan.

Kasim, A. Syarifudin. 1995. Pengantar Ekonomi Produksi. Lambung Mangkurat University Press. Fakultas Pertanian UNLAM. Banjarbaru.

Kasim, A. Syarifudin.1997. Petunjuk Praktis Menghitung Keuntungan dan Pendapatan Petani. Fakultas Pertanian UNLAM. Banjarbaru.

Kasim, A. Syarifudin. 2004. Petunjuk Praktis Menghitung Keuntungan dan Pendapatan Usahatani. Fakultas Pertanian UNLAM. Banjarbaru. 
Konore, A., 2017. Studi Komparasi Distribusi Pendapatan Petani Wilayah Berbasis Sawah dan Hortikultura di Kota Tomohon. Skripsi Fakultas Pertanian, Universitas Sam Ratulangi. Manado.

Masitha, G. 2016. Studi Komparatif Petani Bermitra dan Tidak Bermitra Pada Usahatani Cabai Merah. Jurnal penelitian. Fakultas Pertanian Universitas Jember.

Martius, E. 2008. Kemitraan agribisnis untuk memberdayakan ekonomi rakyat. Jurnal Agribisnis Kerakyatan. Program Studi Agribisnis Fakultas Pertanian Unand : Padang.

Nurdiansyah, A., 2015. Analisis Pendapatan dan Pemasaran Kakao di Kecamatan Sekampung Udik Kabupaten Lampung Timur. Jurnal Fakultas Pertanian, Bandar Lampung.

Nazir, M. 1999. Metode Penelitian. Ghalia Persada Indonesia, Jakarta.

Oktavianus P, Lina, T, P., Lyndon R. J. P. 2017. Analisis Usahatani Labu Kuning. Jurnal Penelitian. Jurusan Sosio Ekonomi Unsrat. Bolaang-Mongondow.

Susanti, N. E., 2015. Kemitraan PT. East West Seed Indonesia Dengan Petani Dalam Usahatani Benih Waluh. Jurnal penelitian. Fakultas Pertanian Universitas Jember.

Sudarto. 2000. Budidaya Waluh. Penerbit Kanisius, Yogyakarta

Sugiyono. 2009. Metode Kualitatif, Kuantitatif dan R \& D. Alfabeta. Bandung.

Shinta, A., 2011. Ilmu Usahatani. Perpustakaan Nasional. Universitas Brawijaya Press.

Suprapti, L., 2005. Dasar - dasar Teknologi Pangan. Vidi Ariesta, Surabaya.

Soekartawi, 2005. Agribisnis Teori dan Aplikasinya. Raja Grafindo Persada, Jakarta.

Soemodiharjo, I. H. 1995. Studi Pengembangan Kemitraan Usaha Agribisnis Jagung Manis di Jawa Timur. Jember: Lembaga Penelitian Universitas Jember.

Sudadi M, Widodo A, 2002. Agribisnis Kemitraan Usaha Bersama. Penerbit Kanisius. Yogyakarta.

Saragih, B., 2001. Agribisnis Paradigma Baru Pembangunan Ekonomi Berbasis Pertanian. Pustaka Wirausaha Muda. Bogor.

Wibowo, 2000. Ekonometrika Analisis data Parametrik. Jember: Fakultas Pertanian Universitas Jember. 